\title{
Precise Estimation of Postpartum Haemorrhage: Difficulties and Importance
}

\author{
H. A. BRANT,* M.R.C.P.ED., F.R.C.S.ED., M.R.C.o.G.
}

The accepted definition of postpartum haemorrhage is an estimated blood loss of at least $500 \mathrm{ml}$. after vaginal delivery. Estimation of blood loss is often unreliable, for few attendants have a clear appreciation of the appearance of $500 \mathrm{ml}$. of blood soaked into linen and the other accoutrements of delivery. Because of the failure to recognize the extent of haemorrhage, its true importance in maternal morbidity and mortality tends to be missed. Several methods have been used in attempts to measure blood loss accurately. Gatch and Little (1924) extracted haemoglobin and measured it as acid haematin by photometric comparison with a series of acid haematin solutions prepared by diluting the patient's venous blood. Pilcher and Sheard (1937) used the spectrophotometer to measure oxyhaemoglobin concentrations. Coller et al. (1944) compared pre- and post-delivery haemoglobin and plasma protein concentrations. Gahres et al. (1962) used chromium-51-labelled red cells to compare the red cell mass before and after delivery, while Spoerel and Heagy (1962) used radioiodinated serum albumin to compare plasma volumes before and after delivery. Murdoch (1958) attempted complete collections in calibrated receptacles.

The aim of the present investigation was to measure the amount of bleeding at vaginal delivery. In order to prevent confusion the estimate made by the attendant will be referred to as the recorded blood loss. The loss determined subsequently by calculation, using the washing-machine extraction method, is referred to as the measured loss.

\section{Subjects}

During a four-month period the postpartum bleeding of 57 patients was measured. The first 33 were taken at random and the next 24 were a random sample of those patients with recorded losses of $200 \mathrm{ml}$. or more. There were 34 multigravidae and 23 primigravidae. Thirty-five had episiotomies or perineal lacerations. Other complications included accidental haemorrhages (2), manual removal of retained placentae (2), forceps deliveries (9), breech deliveries (3), and twin deliveries (3). Three of these abnormal cases were given general anaesthetics. Ergometrine $0.5 \mathrm{mg}$. with hyaluronidase was given intramuscularly with the birth of the anterior shoulder in all cases and further ergometrine was given when bleeding was not adequately controlled.

\section{Method}

After delivery all blood and blood-stained fabrics were placed in cold tap-water (the haemolytic agent) in the bowl of an agitator type of domestic washing-machine. The numbers of the various types of articles were noted. Blood was wiped from the floor and delivery table. Blood clots and blood adherent to the placenta were poured into the washing-machine through a

- Senior Registrar and Tutor, Department of Obstetrics and Gynaecology, Hammersmith Hospital, London $\mathbb{W} .12$, and the Institute of Obstetrics and Gynaecology, London S. University College Hospital and First Assistant, Obstetric bag made of tubular stockinet. Swabs and paper pads were counted and placed loosely in stockinet bags. After immersion in water the bags were passed several times through the washing-machine wringer to break up blood clots. After a few minutes' agitation to expel trapped air the fabrics were totally immersed and the water level was brought to the 48-1. mark. Then $15 \mathrm{ml}$. of concentrated (880 vols.) ammonium hydroxide was added to keep proteins from interfering with haemoglobin measurements; $5 \mathrm{ml}$. of Nonidet $\mathrm{P}-40$ (a surface-active agent) was added to accelerate release of haemoglobin from small clots. The solution was agitated for 45 minutes.

A sample of the resulting solution was centrifuged and filtered. Its oxyhaemoglobin concentration was measured in a Unicam photoelectric colorimeter with an Ilford 625 filter. The volume of water displaced by each type of article in the washing-machine bowl had previously been determined. By subtracting the sum of these volumes from 481 . the total volume of the liquid phase was calculated. The oxyhaemoglobin concentration of a sample of the patient's venous blood taken about the time of delivery was measured.

The blood loss was calculated from the formula

$$
\text { Blood loss }=\frac{\mathbf{V} \times \mathbf{C}_{\mathrm{i}}}{\mathrm{C}_{\mathrm{v}}} \mathrm{ml}
$$

Where $\mathrm{V}$ is volume in millilitres of the liquid phase in the bowl $C_{b}$ is the concentration of haemoglobin in the solution from the bowl and $C_{v}$ the concentration of haemoglobin in the venous sample.

The attendant recorded a clinical estimate of the quantity of blood lost.

Controls.-(1) Five samples of fresh blood of known haemoglobin content and varying in volume between 100 and 300 $\mathrm{ml}$. were allowed to clot in bins containing linen fabrics. The haemoglobin was recovered from each with errors of less than $2 \%$. (2) An excess of calcium ions was added to known quantities of haemoglobin in six samples of old stored blood varying in volume between 400 and $1,000 \mathrm{ml}$. These were spilt on the floor and on to fabrics, and again the errors of recovery were less than $2 \%$. (3) Solutions of liquor amnii and of meconium in concentrations greater than would occur in the solution in the washing-machine bowl were not found to cause measurable absorption in the oxyhaemoglobin wave band.

\section{Determination of the Significance of the Losses}

The blood losses recorded at the time of delivery were compared with the subsequent measurements.

The volume of any blood transfused was deducted from the measured loss to give the net deficit. (The volume of the transfused blood was corrected to the same haemoglobin concentration as the patient's blood after assuming that one bottle of blood contains $470 \mathrm{ml}$. of blood of $11 \mathrm{~g} . / 100 \mathrm{ml}$. haemoglobin concentration.) An attempt was made to correlate the net blood deficit with the pulse rate and blood pressure recorded during the first hour after delivery and with alterations of venous haemoglobin concentrations from delivery to the third, sixth, and eighth days of the puerperium. 
Though accurate measurements of blood losses were made for only a sample of all the patients delivered in the unit, the approximate frequency with which measured losses greater than $500 \mathrm{ml}$. occurred was calculated as follows. The recorded blood losses, of each second patient delivered during the fourmonth period of the investigation were abstracted from the case records and grouped according to the amounts of these recorded losses (Table I). The number in each group was then expressed as a percentage of the total number of vaginal deliveries. The II shows the percentage among the studied patients of each group of recorded losses who had measured losses of $500 \mathrm{ml}$. or more. Applying these percentages to column 3 of Table I, one calculates column 4-the contribution of each group of recorded losses to the percentage with measured losses greater than $500 \mathrm{ml}$. Adding column 4 gives the percentage of vaginal deliveries which would ':e associated with measured losses of more than $500 \mathrm{ml}$.- that is, the measured postpartum haemorrhage rate.

Though patients whose blood losses were measured included a larger than usual number with abnormal deliveries, this did not have an important bearing on the above calculation. Table III shows that when the cases are grouped according to the

\begin{tabular}{|c|c|c|c|}
\hline $\begin{array}{l}\text { Groups } \\
\text { of } \\
\text { Recorded } \\
\text { Losses }\end{array}$ & $\begin{array}{c}\text { Percentage of } \\
\text { All Patients } \\
\text { with Recorded } \\
\text { Losses } \\
\text { in These } \\
\text { Groups }\end{array}$ & $\begin{array}{c}\text { In Each Group } \\
\text { Percentage of } \\
\text { Study Patients } \\
\text { Losing More } \\
\text { than } 500 \mathrm{ml} \text {. } \\
\text { (from Table II) }\end{array}$ & $\begin{array}{l}\text { Contribution of Each } \\
\text { Group of Recorded } \\
\text { Losses to Percentage } \\
\text { who would have } \\
\text { Measured Losses of } \\
\text { More than } 500 \mathrm{ml} \text {. }\end{array}$ \\
\hline 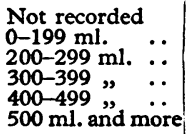 & $\begin{array}{r}2 \cdot 5 \\
56 \cdot 8 \\
26 \cdot 0 \\
5 \cdot 3 \\
3 \cdot 3 \\
6 \cdot 0\end{array}$ & $\begin{array}{r}0 \\
0 \\
33 \\
66 \\
100 \\
100\end{array}$ & $\begin{array}{c}0 \\
0 \\
8.7(33 \% \text { of } 26 \cdot 0) \\
3.5(66 \% \text { of } 5 \cdot 3) \\
3.3(100 \% \text { of } 3.3) \\
6.0(100 \% \text { of } 6.0)\end{array}$ \\
\hline
\end{tabular}

The percentage of vaginal deliveries with losses more than $500 \mathrm{ml}$. was therefore 21.5 (the measured " postpartum haemorrháge" rate).

TABLE II

\begin{tabular}{|c|c|c|c|c|c|c|c|c|c|}
\hline \multirow[t]{2}{*}{$\therefore$} & \multicolumn{9}{|c|}{ Groups of Recorded Losses } \\
\hline & $|0-199|$ & $|200-|$ & $300-$ & $400-$ & $500-1$ & $|000-699|$ & 800 & 900 & 1,500 \\
\hline $\begin{array}{l}\text { Measured } \\
\text { losses of these } \\
\text { patients }\end{array}$ & $\begin{array}{r}50 \\
70 \\
190 \\
220 \\
230 \\
240 \\
300 \\
320 \\
350 \\
410 \\
450\end{array}$ & $\begin{array}{l}240 \\
240 \\
250 \\
260 \\
300 \\
330 \\
370 \\
410 \\
470 \\
480 \\
550 \\
550 \\
570 \\
600 \\
850\end{array}$ & \begin{tabular}{|r|}
290 \\
330 \\
380 \\
490 \\
530 \\
560 \\
580 \\
630 \\
800 \\
810 \\
1,030 \\
1,250
\end{tabular} & \begin{tabular}{|r|}
530 \\
560 \\
650 \\
720 \\
720 \\
760 \\
1,010 \\
1,180 \\
$1,240^{*}$ \\
2,180 \\
\end{tabular} & 950 & $\begin{array}{r}720 \\
960 \\
1,640^{*}\end{array}$ & $\begin{array}{l}1,400^{*} \\
2,360^{*}\end{array}$ & $\begin{array}{l}1,220^{*} \\
2,700^{*}\end{array}$ & $2,000^{*}$ \\
\hline $\begin{array}{l}\text { Percentage in } \\
\text { each group } \\
\text { with measured } \\
\text { losses of } 500 \\
\text { ml. or more }\end{array}$ & 0 & 33 & 66 & 100 & 100 & 100 & 100 & 100 & 100 \\
\hline
\end{tabular}

TABLE III.-Measured Losses of $500 \mathrm{ml}$. or More Occurring in Normal and Abnormal Vaginal Deliveries

\begin{tabular}{|c|c|c|c|c|}
\hline \multicolumn{3}{|c|}{$\begin{array}{l}\text { Recorded Losses } \\
(\mathrm{ml} .)\end{array}$} & $\begin{array}{l}\text { No. in } \\
\text { Group }\end{array}$ & $\begin{array}{l}\text { No. with Loss Greater } \\
\text { than } 500 \mathrm{ml} \text {. (Measured) }\end{array}$ \\
\hline 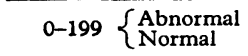 & $\because$ & 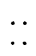 & $\begin{array}{l}3 \\
8\end{array}$ & $\begin{array}{l}\mathbf{0} \\
\mathbf{0}\end{array}$ \\
\hline 2C0-299 $\left\{\begin{array}{l}\text { Abnormal } \\
\text { Normal }\end{array}\right.$ & $\because$ & 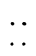 & $\begin{array}{l}7 \\
8\end{array}$ & $\begin{array}{l}3 \\
2\end{array}$ \\
\hline 300-399 $\left\{\begin{array}{l}\text { Abnormal } \\
\text { Normal }\end{array}\right.$ & $\cdots$ & $\cdots$ & 11 & $\begin{array}{l}1 \\
7\end{array}$ \\
\hline $400-499\left\{\begin{array}{l}\text { Abnormal } \\
\text { Normal }\end{array}\right.$ & 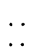 & $\ldots$ & $\begin{array}{l}4 \\
6\end{array}$ & $\begin{array}{l}4 \\
6\end{array}$ \\
\hline $\begin{array}{c}\text { More than } \\
500\end{array}\left\{\begin{array}{l}\text { Abnormal } \\
\text { Normal }\end{array}\right.$ & $\because$ & $\because$ & $\begin{array}{l}4 \\
5\end{array}$ & $\begin{array}{l}4 \\
5\end{array}$ \\
\hline
\end{tabular}

recorded losses these abnormal cases in each of the groups had only slightly greater proportions with more than $500 \mathrm{ml}$. losses than did the normal cases in the corresponding groups.

\section{Results}

Table II compares the measured with the recorded losses. It is quite clear that for small losses records are reasonably correct, but as the recorded loss increases the amount of underestimation increases, so that with large losses there are serious discrepancies. (The measured losses of $2,360 \mathrm{ml}$. and $2,700 \mathrm{ml}$., which were recorded as 800 and $900 \mathrm{ml}$. respectively, were associated with cases of concealed accidental haemorrhage. The retroplacental clots were firm and represented a surprisingly large amount of blood.)

This investigation took place in a well-equipped unit where personnel are aware of the dangers of haemorrhage. The findings confirm the impression that it is usual to underestimate blood loss. It is often not appreciated that large volumes of blood can be absorbed by fabrics.

The alterations which occurred in haemoglobin levels between delivery and the third and subsequent days of the puerperium did not show any correlation with the net blood deficits.

Increase of pulse rate and fall of blood pressure occurred only with the largest blood losses. The calculations set out in Table I are included to emphasize the extent of the haemorrhage problem in obstetrics.

\section{Discussion}

When $21.5 \%$ of patients lose more than $500 \mathrm{ml}$. of blood at vaginal delivery it is essential that all should come to delivery free from anaemia and in the best possible general condition.

There is no evidence that blood loss expressed as a percentage of total blood volume is of less significance in obstetrical than in surgical patients. The vital signs of depleted blood volume are a systolic pressure below $100 \mathrm{~mm}$. $\mathrm{Hg}$ and a pulse rate above 100 beats per minute. Transfusion should not be delayed until they are present, as they are late signs and their appearance indicates commencing failure of the compensatory mechanisms. The blood volume may then be reduced by 30 to $35 \%$, which means that an obstetric patient may have lost between 1,500 and $2,000 \mathrm{ml}$. Though these signs appear readily with rapid blood loss, they may not be present until the patient is approaching exsanguination if the blood loss has been slow and repeated.

The prevention of overt shock should not be the only aim in the management of haemorrhage. Before it appears there may be considerable vasoconstriction in the renal and pituitary circulations, so that, especially when other factors such as toxaemia, infection, or fibrin deposition are present, necrosis in these organs may be precipitated. Schneeberg et al. (1960) did not find any correlation between the severity of haemorrhage or the profundity of shock and the subsequent appearance of panhypopituitarism.

When the blood pressure is normal $(100-140 \mathrm{~mm}$. Hg systolic), indicating a blood volume greater than $70 \%$, other signs are of value in assessing the extent of blood loss. These are facial pallor, minor changes in pulse rate, and coldness of the fingers, ears, and nose (Grant and Reeve, 1951). Even so, the amount lost is best determined by close observation of the bleeding as it occurs combined with an ability to make a realistic estimate of the loss. This ability can be developed by checking clinical estimates with a method of accurate measurement.

The findings in the present investigation are consistent with the conclusion of Thornton (1963) that the loss from a healthy adult, even when lightly anaesthetized, need be replaced only when it is greater than $500 \mathrm{ml}$. Nevertheless, the loss of 300 ml. warns that further bleeding may follow. Steps should 
then be taken to cross-match blood, empty the uterus, give further oxytocics, and repair genital trauma. The report by the Ministry of Health (1963) on maternal deaths in England and Wales for the years 1958-60 emphasized the frequency with which attendants failed to realize the serious state of patients who had bled. Considerable underestimation of the extent of blood loss often contributed to this failure. Of the 742 deaths studied 130 were believed to have haemorrhage as the primary factor leading to death. In 61 of these (31 with avoidable factors) the bleeding was postpartum.

This investigation has shown that in routine hospital praciice there is considerable underestimation of blood loss, and yet this hospital is representative of those with a high standard of antenatal and intranatal care.

The present finding of virtually invariable underestimation, especially when the recorded loss exceeds $300 \mathrm{ml}$., suggests most strongly that unappreciated and underestimated blood loss is a much more important factor in many maternal deaths than available statistics show.

Reports have appeared in which the criterion for assessing the effect of anaesthetic and oxytocic preparations on the third stage of labour has been the incidence of postpartum haemorrhage (Embrey et al., 1963 ; Friedman, 1957 ; McBride, 1954). The findings in this survey suggest that this criterion is of little value unless clinical estimation of blood loss is replaced by accurate measurement.

It is hoped that the present investigation will emphasize to those attending vaginal deliveries how often considerable haemorrhages occur, so that by early action disastrous exsanguinations will be avoided.

\section{Summary}

A method of accurately measuring blood loss is outlined. Blood is extracted in a washing-machine and measured spectro- metrically as oxyhaemoglobin. The bleeding that occurred after 57 vaginal deliveries was measured. When this measured amount was compared with the estimate recorded at the time of delivery the estimate was reasonably correct for small losses. However, when the recorded loss exceeded $300 \mathrm{ml}$. underestimation was invariable, and as the loss became greater so did the amount of underestimation. On the basis of these measurements it is calculated that in over $20 \%$ of vaginal deliveries the blood loss exceeds $500 \mathrm{ml}$. A systolic blood pressure below $100 \mathrm{~mm}$. Hg and a pulse rate above 100 beats per minute are late signs of depleted blood velume and indicate commencing failure of the compensatory mechanisms.

I wish to thank Mr. H. G. Dixon and Mr. W. G. MacGregor for their help and advice; Professor J. C. McClure Browne for permission to study the patients; Miss C. M. Miller and the midwives for their co-operation; Mr. E. Simmonds for technical advice and assistance; Dr. A. G. Hawkes, of the Statistics Department of University College, for assistance in checking the statistical significance of the data; and, finally, the directors of Associated Electrical Industries, Hotpoint Ltd., for their generosity in donating the washing-machine.

REFERENCES

Coller, F. A., Crook, C. E., and Iob, V. (1944). F. Amer. med. Ass.,

Embrey, M. P., Barber, D. T. C., and Scudamore, J. H. (1963). Brit. med. Y., 1, 1387

Friedman, E. A. (1957). Amer. 7. Obstet. Gynec., 73, 1306.

Friedman, E. A. (1957). Amer. F. Obstet. Gynec., 73, 1306. Obstet. and Gynec., 19, 455 .

Gatch, W. D., and Little, W. D. (1924). F. Amer. med. Ass., 83, 1075. Grant, R. T., and Reeve, E. B. (1951). Spec. Rep. Ser. med. Res. Coun. (Lond.), No. 277, p. 3 .

McBride, W. (1954). Med. F. Aust., 1, 118

Ministry of Health (1963). Reports on Public Health and Medical Subjects, No. 108. Report on Confidential Enquiries into Maternal Deaths in England and Wales, 1958-1960, p. 13. London.

Murdoch, R. (1958). Lancet, 2, 731.

Pirdoch, R. (19) Sheard, C (1937). Proc. Mayo Clin., 12, 209.

Pilcher, F., and G. G., Perloff, W. H., and Israel, S. L. (1960). 7. Amer. med. Ass., 172, 20.

Spoevel, W. E., and Heagy, F. C. (1962). Canad. F. Surg., 5, 25.

Thornton, J. A. (1963). Ann. roy. Coll. Surg. Engl., 33, 164.

\title{
Some Factors Affecting Bacterial Colony Counts in Urinary Infection
}

\author{
A. P. ROBERTS,* B.SC. ; R. E. ROBINSON,† F.R.C.S. ; R. W. BEARD, $\ddagger$ M.B., M.R.C.O.G.
}

Brit. med. F., 1967, 1, 400-403

Colony counting is the numerical estimation of the number of viable organisms in a millilitre of uncentrifuged urine. This quantitative estimation enables true bacteriuria to be differentiated from urethral or vulval contamination which may occur when midstream or " clean catch" urine is collected (Marple, 19.1 ; Kass, 1957). A count of more than 100,000 organisms per ml. of urine is generally regarded as diagnostic of infection, although, as Kass (1962) has pointed out, the accuracy of the diagnosis is improved from 80 to $96 \%$ if two consecutive specimens from the same patient are cultured. At the other end of the scale it is thought unlikely that urinary infection is present if the colony count of the midstream urine is less than 10,000 organisms per ml. A colony count between these two levels is thought to signify urine infection in only $5 \%$ of cases. Bradley and Little (1963) have shown that colony counting is superior to semiquantitative assessments of bacteriuria such as

\footnotetext{
* Research Assistant.

Resident Medical Officer.

F Senior Lecturer. London.
}

"heavy" or "scanty" growth, but the danger in the use of colony counts for diagnosis lies in the too rigid adherence to the absolute levels mentioned.

Certain factors, such as the rate of flow of the urine, the amount of vaginal discharge in women, and the method of collection of the midstream specimen, may affect the level of bacteriuria so considerably that occasionally a false-positive or false-negative diagnosis may result. In addition, in routine hospital practice the collection of the midstream specimen is often left to nursing staff who may be inexperienced in the technique, and almost always the diagnosis of urinary infection is made on the result obtained from a single specimen. This is unfortunate, but because of shortage of staff it may be unavoidable. Undoubtedly the ideal method of collecting urine in women, to avoid contamination, is by the suprapubic route, when the finding of even small numbers of organisms in the specimen is evidence of urinary infection (Stamey et al., 1965 ; Beard et al., 1965), but this technique is not always practicable. In this study the extent to which some of thes: factors affect the quantitative assessment of urine infection in a 